\title{
Mediating Effects of Digital Technology on Entrepreneurial Orientation and Firm Performance : Evidence from Small and Medium-sized Enterprises (SMEs) in Indonesia
}

\author{
Anton Wardaya, Sasmoko, Idris Gautama So, Agustinus Bandur
}

\begin{abstract}
Small and Medium sized enterprises (SMEs) plays important role in Indonesia economic. It contributes to $99.9 \%$ of national economic, $97 \%$ to employment and $60.34 \%$ to Indonesia GDP. Moreover, Indonesia is known to be one of the most internet users. However, currently, there is lack of studies to understand the role of digital technology and entrepreneur orientation on influencing the performance of SME's in Indonesia. This study aims to develop a conceptual model linking entrepreneurial orientation, digital technology capability and SME performance. This study is using Systematic literature review (SLR) method. The result of SLR was used as the based for the concept development. More than 1100 publication published from 2010 to 2019 were screened with entrepreneurial orientation, digital technology and SMEs' performance as keywords. Finally, 34 journals were included for this review. Based on the review there were three possible relationships in the conceptual model which are (1) there is a positive relationship between entrepreneurial orientation and firm performance; (2) there is a positive relationship between entrepreneurial orientation and digital technology capability and (3) there is a positive relationship between digital technology capability and firm performance. It concludes with the need for further study to find empirical validation of the three relationships. Contribution of this study is giving the conceptual framework that both entrepreneurial orientation and digital technology capability might have important roles to SMEs' performance in Indonesia
\end{abstract}

Keywords: digital technnology, entrepreneurial orientation, SMEs' performance.

\section{INTRODUCTION}

Indonesia is one of the countries with the largest number of internet accesses in the world. Based on a survey conducted by APJII (2017), the penetration of internet users was 143.26 million or $54.68 \%$ of the total population of Indonesia. When compared to internet users in Indonesia in increase in internet users by 33.06 million within 2 years (2015-2017). Based on a survey conducted by APJII (2017), it was noted that there were 371.4 million registered mobile users; 132.7 million internet users and 106 million active social media users. Based on a survey conducted by We are

Revised Manuscript Received on April 19, 2019.

Anton Wardaya, Doctor of Research in Management, Bina Nusantara University, Jakarta 11530, Indonesia

Sasmoko, Leader in the Research interest Group in Educational Technology, Bina Nusantara University, Jakarta 11530, Indonesia

Idris Gautama So, School of Business Management in Bina Nusantara University, Jakarta 11530, Indonesia

Agustinus Bandur, Lecturer \& Strategic Research and Partnership Team Leader in Bina Nusantara University, Jakarta 11530, Indonesia 2014 amounting to 110.2 million users, there was an

Social (2019), the average netizen spends time using the internet is 8 hours 36 minutes / day and for using social media an average of 3 hours 26 minutes / day. This indicates that using the internet and social media has become a habit in Indonesia.

In Indonesia, SMEs contribute $99.9 \%$ in the national economy (Tambunan, 2007) and employment reaches $97 \%$ and SMEs contribute to GDP up to $60.34 \%$ (Hani, Rachmania, Setyaningsih, \& Putri, 2012). When viewed in the economic crisis that had hit Indonesia in 1998, the Indonesian economy was still relatively stable, because it was supported by a large population of SMEs. SMEs experienced a smaller impact due to the crisis that hit in 1998, compared to large industries, because SMEs were more flexible and responded more quickly to sudden crises (Berry, Rodriguez, \& Sandee, 2001; Marino, Lohrke, Hill, \& Weaver, 2008). In 2017, MSMEs contributed Rp. 13,600 trillion or around $60 \%$ of the total Gross Domestic Income (GDP), where Micro Enterprises contribute around Rp. 5,000 trillion per year, small businesses around Rp. 1300 trillion, medium-sized businesses around Rp. 1800 trillion and businesses. big around Rp. 5,000 trillion.

The Ministry of Cooperatives and SMEs (2017) shows that micro businesses only have an average income of around Rp 85 million per year or Rp 283 thousand per day, small businesses Rp 1.84 billion per year or $\mathrm{Rp} 6.1$ million per day and medium businesses Get Rp. 28.5 billion per year or around Rp. 95 million per day and large businesses earn around Rp. 1.1 trillion per year or Rp. 3.6 billion per day (assumed 1 year is 300 days). This shows that the productivity per business unit does increase according to the type of business. Big business productivity is 38 times that of medium-sized businesses, 543 times small businesses and 11760 times micro-businesses.

Moreover, the productivity of micro-enterprises is still far lower than that of small and medium enterprises which are more easily fragile or unstable and easily crushed due to intense competitive pressures. Micro-businesses need to open themselves to rapidly developing technological developments, for example in utilizing digital technology that can free markets and produce production costs. According to the Annual Report of European SMEs (2016/2017), it was seen that the number of MSMEs in developed countries was also assessed by MSMEs, 
amounting to $99.8 \%$ while micro businesses were only $93 \%$. While the structure of MSMEs in Indonesia is very important by micro-enterprises, which is $98.7 \%$ and unchanged from 10 years ago. This shows that microbusinesses in Indonesia never scaling up to small or medium-sized businesses.

\section{METHODOLOGY}

The authors used PRISMA systematic review (Liberati et al., 2009) for searching journals that related with research. Authors search keywords "Entrepreneurial Orientation", "Digital Technology" and "Firm Performance" in Science Direct. The authors found 1154 journal publications. The authors then limited the year of journal's publication from 2014 until 2018 and found 456 journal publications.

The authors then limited the source to Social Science journals, namely Journal of Business Research, Procedia Social and Behavior, Information \& Management, International Business Review. After reviewing duplication and relevant, 65 journals published from 2014 to 2018 were found. After screening based type of relevant industry and methodology, finally 34 journals were included in the systematic review.

\section{RESULTS}

The authors review thirty four journals and found that there are three main topic. The first one discusses the relationship between Entrepreneurial Orientation and Firm Performance. The second category is the relationship between Entrepreneurial Orientation and Digital Technology Capability. The last category is about the relationship between Digital Technology Capability and Firm Performance.

\subsection{Entrepreneurial Orientation and Firm Performance}

The concept of entrepreneurial orientation is central to the entrepreneurial domain (Green \& Slevin, 2006). Entrepreneurial orientation is a method and how to make decisions that are used to act as entrepreneurs and is a type of strategic orientation of a company that wants to compete (Lumpkin \& Dess, 1996). Another researcher, Bouncken, Plu, Pesch, \& Kraus, (2014), argues that entrepreneurial orientation is defined as the company's competence to identify and utilize opportunities with the aim of creating value. Entrepreneurial orientation is the company's strategy towards entrepreneurship (Anderson, Kreiser, \& Donald, 2014). According to (Dehghan, 2015), entrepreneurial orientation is seeing opportunities to create value and improve company performance through innovation. Entrepreneurship orientation can be interpreted as a mindset, behavior and decision-making process that supports the company's strategy in practice, competition and management (Hughes et al., 2015).

SME performance can be measured by financial and nonfinancial performance. Financial performance consists of financial efficiency such as investment, profits from sales and net profit margins (Y. Li, Huang, \& Tsai, 2009). While non-financial performance includes customer satisfaction, market growth and customers. The performance evaluation of SMEs is simpler than the assessment of the performance of large companies. Measurement of a company's performance can be seen from value-based assessments. The good performance of SMEs results in the growth of their business getting better and bigger.

In general, SMEs use financial performance indicators, because SMEs lack the human resources needed to measure their performance (Heilbrunn, 2014). SMEs measure their growth with turnover growth and employment growth (Güldenberg, 2014). The SME performance appraisal is best viewed from a financial perspective. In this case, the financial assessment used is increasing sales and increasing profits (Sidik, 2012). The success of an SME is largely determined by the participation of the people in it (Sinisammal, Belt, \& Harkonen, 2012).

\subsection{Entrepreneurial Orientation and Digital Technology} Capabilities

According to Teece et all. (1997), rapid technological change requires high dynamic capabilities. The development of this technology helps companies to be able to take advantage and market opportunities that require an understanding of the needs that consumers want now, when they need it and at what price is in accordance with the ability of consumers. Capability of digital technology is the ability to access all information with the help of technology (Azubuike, 2013).

According to other researchers, Pranita (2018), the capability of digital technology is one of the functional capabilities in the process, practice and connection with customers through digital media. There are four dimensions of digital technology capabilities, namely the ability to provide information, the ability to share information, context awareness capabilities and tagging capabilities. Besides that digital technology is able to innovate to create new products and new values (Chen, Tang, Jin, Xie, \& Li, 2014).

In the face of the 4.0 industrial revolution, technology has a very important role. Economic actors must be technologically literate so that they can get the highest benefit by using these tools namely technology (MartínRojas, García-Morales, \& Bolívar-Ramos, 2013). The rapid development of information technology has changed the way of thinking and behaving in society. Digital technology transforms the economic order from classical economics into a digital economy. Information technology encourages a country's economic growth which can be seen from national income (GDP). Information technology also succeeded in creating many new jobs.

\subsection{Digital Technology Capabilities and Firm Performance}

Mastery of the latest technology for SMEs in developing countries is needed so that they can compete in the international market (Lahovnik \& Breznik, 2014). The latest technology includes internet technology. The capability of internet technology is very important in helping SMEs to reach new markets even at the international level (Bianchi, 2017). Capability to technology at any level has a significant 
influence on the performance of SMEs (Jirayuth Chantanaphant, Nabi, \& Dornberger, 2013). Even Lahovnik and Breznik, (2014); Bianchi, 2017 emphasizes the dominant source of competitiveness superiority to the performance of a company is the capability of technological innovation. Companies can have the ability to provide access to a wider range of markets. Companies can find out the needs and values perceived by their customers. So technological capabilities are needed to support company performance.

The performance of SMEs is influenced by the knowledge and attitudes of business owners / managers about information technology (Quinton, Canhoto, Molinillo, Pera, \& Budhathoki, 2018). Changes in the market due to the presence of digital technology require SMEs to improve their capabilities. SMEs are transformed into businesses that used to be conventionally turned into technology-based businesses. Businesses that do not follow technological developments will be eroded by the era. SMEs must be aware of reading business opportunities that are faster and able to optimize the opportunities provided in this digital age. Besides listening to responses that come from consumers and competitors and responding to customer needs that are constantly changing (Yoon \& George, 2013). Technology makes people quick to innovate so that it can be a mediation between entrepreneurial orientation and company performance (Shan, Song, \& Ju, 2015). SMEs can determine the best strategy in facing market competition with digital technology so that their performance becomes better and directed.

All organizations that use digital technology for internal operations, business processes and managing strategies, can transition into larger scale organizations (Tumbas, Be rente and Vom Brocke, 2018). With the help of technology, organizations can change direction faster (Woodard, Ramasubbu, Tschang, \& Sambamurthy, 2012) reach larger markets even to international markets (J Chantanaphant, Nabi, \& Dornberger, 2015), connect with global supply chains, track cost effective customers and improve internal operations (Mazzarol, 2015), products and services throughout the industry are becoming faster, opportunities for entrepreneurship are even greater (Nambisan, 2017), increasing processes and production is greater and increasing competitiveness (Hamdani \& Wirawan, 2012; Lahovnik \& Breznik, 2014). With the help of digital technology, entrepreneurs with limited resources can make their business succeed. (L. Li, Su, Zhang, \& Mao, 2017). Adoption of technology is one of the SME strategies because it can increase SME productivity, minimize operational costs, increase the effectiveness of SMEs, reduce environmental impacts and energy costs (Arifin, 2015)

\section{DISCUSSION}

The authors propose a relationship between entrepreneurial orientation, digital technology capabilities, and firm performance.

P1: Entrepreneurial Orientation has a positive direct influence on firm performance

P2: Entrepreneurial Orientation will positively influence digital technology capabilities
P3: Digital technology capabilities will positively influence firm performance

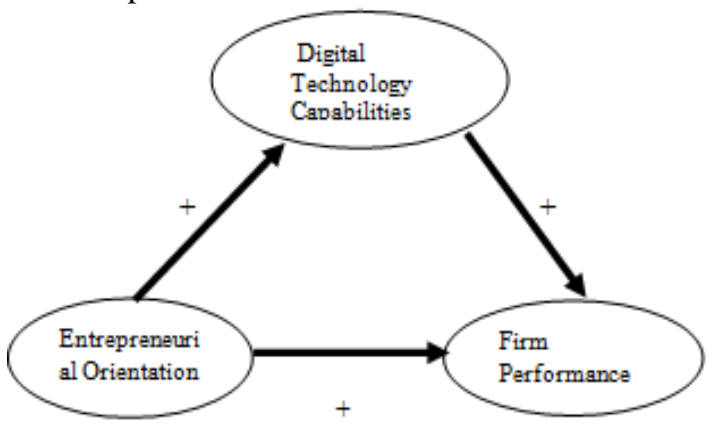

Figure 1. Propose Model Relationship of Entrepreneurial Orientation, Digital Technology Capabilities and Firm Performance

\section{CONCLUSION}

In this literature review, the authors suggest that there are three possible relationships between entrepreneurial orientation, digital technology capabilities and firm performance. The first relationship is that entrepreneurial orientation has a positive direct influence on firm performance. Second one is that entrepreneurial orientation will positively influence digital technology capability. The last is that digital technology capability will positively influence firm performance. This study is limited that the literature review is only based on one search engine which is Science Direct. Further study to discover empirical validation of the three relationships between entrepreneurial orientation, digital technology capabilities and firm performance.

Further study with evidence will contribute to theoretical and practical implication. The theoretical contribution will provide evidence of the relationship between entrepreneurial orientation, digital technology capabilities and firm performance. The practical implication will give another insight for owner or manager of sme that digital technology can be used to improve firm performance.

\section{REFERENCES}

1. TAMBUNAN T. Entrepreneurship Development: Smes in Indonesia. J Dev Entrep [Internet]. 2007;12(01):95118. Available from: http://www.worldscientific.com/doi/abs/10.1142/S10849 46707000575

2. Hani U, Rachmania IN, Setyaningsih S, Putri RC. Patterns of Indonesian Women Entrepreneurship. Procedia Econ Financ [Internet]. 2012;4(Icsmed):274$85 . \quad$ Available from: http://linkinghub.elsevier.com/retrieve/pii/S22125671120 03425

3. Berry A, Rodriguez E, Sandee H. Small and medium enterprise dynamics in Indonesia. Bull Indones Econ Stud. 2001;37(3):363-84.

4. Marino LD, Lohrke FT, Hill JS, Weaver KM. E $\mathrm{T} \& \mathrm{P}$ Formation Intentions in an 
Emerging Economy: in Indonesia. Entrep Theory Pract. 2008;32(205):157-83.

5. Mikro U. Perkembangan data usaha mikro, kecil, menengah (umkm) dan usaha besar (ub) tahun 2016 . 2017. 2017;(1):2016-7.

6. $\quad$ Market I. ANNUAL REPORT ON EUROPEAN SMEs Annual Report on European SMEs. 2017.

7. Liberati A, Altman DG, Tetzlaff J, Mulrow C, Gøtzsche PC, John PA. The PRISMA statement for reporting systematic reviews and meta-analyses of studies that evaluate healthcare interventions: explanation and elaboration. BMJ. 2009;399:1-28.

8. Green KM, Slevin DP. E T \& P. 2006;57-81.

9. Lumpkin GT, Dess GG. Clarifying the Entrepreneurial Orientation Construct and Linking It to Performance Author ( s ): G . T . Lumpkin and Gregory G . Dess Source : The Academy of Management Review, Vol . 21 , No . 1 ( Jan ., 1996 ), pp . 135-172 Published by: Academy of Man. Acad Manag [Internet] 1996;21(1):135-72. Available from: files/3510/Lumpkin, Dess - 1996 - Clarifying the Entrepreneurial Orientation Construct and Linking It to Performance Author ( s ) G . T. Lumpkin a.pdf

10. Bouncken RB, Plu BD, Pesch R, Kraus S. Entrepreneurial orientation in vertical alliances: joint product innovation and learning from allies. 2014;

11. Anderson BS, Kreiser PM, Donald F. RECONCEPTUALIZING ENTREPRENEURIAL ORIENTATION. 2014;(May).

12. Dehghan A. the Effects of Customer and Entrepreneurial Orientation on Innovativeness and Performance. 2015;08(04):357-64.

13. Hughes M, Lane MH, Dh D, Eggers F, Lane MH, Dh D. The relevance of slack resource availability and networking effectiveness for entrepreneurial orientation Sascha Kraus Paul Hughes. 2015;26(1):116-38.

14. Li Y, Huang J, Tsai M. Industrial Marketing Management Entrepreneurial orientation and fi rm performance: The role of knowledge creation process. Ind Mark Manag [Internet]. 2009;38(4):440-9. Available from: http://dx.doi.org/10.1016/j.indmarman.2008.02.004

15. Heilbrunn S. A DEA based taxonomy to map successful SMEs A " DEA " Based Taxonomy to Map Successful SMEs. 2014;(October).

16. Güldenberg KLS. Generic strategies and firm in SMEs : performance a longitudinal study of Austrian SMEs. 2014;35(2):169-89.

17. Sidik IG. Conceptual framework of factors affecting SME development: Mediating factors on the relationship of entrepreneur traits and SME performance. Procedia Soc Behav Sci [Internet]. 2012;4(Icsmed):373-83 Available from: http://dx.doi.org/10.1016/S22125671(12)00351-6

18. Sinisammal J, Belt P, Harkonen J. Successful Performance Measurement in SMEs through Personnel Participation. Am J Ind Bus Manag [Internet]. 2012;2012(April):30-8. Available from: http://www.scirp.org/Journal/PaperInformation.aspx?pap erID $=18840$

19. Jose S. DYNAMIC CAPABILITIES AND STRATEGIC MANAGEMENT. 1997;18(April 1991):509-33.

20. Azubuike VMU. Technological Innovation Capability and Firm' s Performance in New Product Development Technological Innovation Capability and Firm's Performance in New Product Development. Commun IIMA. 2013;13(1):42-56.

21. Pranita D. Digitalization: The Way to Tourism Destination's Competitive Advantage (Case Study of Indonesia Marine Tourism). KnE Soc Sci [Internet]. 2018;3(11):243.
https://knepublishing.com/index.php/Kne-

Social/article/view/2763

22. Chen Y, Tang G, Jin J, Xie Q, Li J. CEOs transformational leadership and product innovation performance: The roles of corporate entrepreneurship and technology orientation. J Prod Innov Manag. 2014;31(S1):2-17.

23. Martín-Rojas R, García-Morales VJ, Bolívar-Ramos MT. Influence of technological support, skills and competencies, and learning on corporate entrepreneurship in European technology firms. Technovation [Internet]. 2013;33(12):417-30. Available from:

http://dx.doi.org/10.1016/j.technovation.2013.08.002

24. Lahovnik M, Breznik L. Technological innovation capabilities as a source of competitive advantage: A case study from the home appliance industry. Transform Bus Econ. 2014;13(2):144-60.

25. Authors F. SME international performance in Latin America The role of entrepreneurial and. 2017;

26. Chantanaphant J, Nabi MNU, Dornberger U. The Effect of Technological Capability on the Performance of SMEs in Thailand. Macrotheme Rev. 2013;2(4):16-26.

27. Quinton S, Canhoto A, Molinillo S, Pera R, Budhathoki $\mathrm{T}$. Conceptualising a digital orientation: antecedents of supporting SME performance in the digital economy. J Strateg Mark [Internet]. 2018;26(5):427-39. Available from: http://dx.doi.org/10.1080/0965254X.2016.1258004

28. Yoon TE, George JF. Why aren't organizations adopting virtual worlds? Comput Human Behav. 2013;29(3):77290.

29. Shan P, Song M, Ju X. Entrepreneurial orientation and performance : Is innovation speed a missing link? J Bus Res [Internet]. 2015; Available from: http://dx.doi.org/10.1016/j.jbusres.2015.08.032

30. Tumbas S, Berente N, Vom Brocke J. Digital Capabilities for Buffering Tensions of Structure, Space, and Time during Entrepreneurial Growth. ICIS 2017 Transform Soc with Digit Innov [Internet]. 2018;(November):1-20. Available from: http://aisel.aisnet.org/icis2017/Strategy/Presentations/21

31. Woodard CJ, Ramasubbu N, Tschang FT, Sambamurthy V. Design Capital and Design Moves: The Logic of Digital Business Strategy. Ssrn. 2012;

32. Chantanaphant J, Nabi NU, Dornberger U. Strategic Advantages Building Through Technological Capability: The Case of SMEs in the Plastics Industry in Thailand. 2015;(Ameit):42-8.

33. Mazzarol T. SMEs engagement with e-commerce, ebusiness and e-marketing. Small Enterp Res [Internet] 2015;22(1):79-90. Available from: http://www.tandfonline.com/doi/full/10.1080/13215906.2 015.1018400

34. Nambisan S. Digital Entrepreneurship: Toward a Digital Technology Perspective of Entrepreneurship. Entrep Theory Pract. 2017;41(6):1029-55.

35. Hamdani J, Wirawan C. Open Innovation Implementation to Sustain Indonesian SMEs. Procedia Econ Financ [Internet]. 2012;4(Icsmed):223-33. Available from: http://linkinghub.elsevier.com/retrieve/pii/S22125671120 03371

36. Li L, Su F, Zhang W, Mao JY. Digital transformation by SME entrepreneurs: A capability perspective. Inf Syst J. 2017;(May):1-29. 
37. Arifin Z. The effect of dynamic capability to technology adoption and its determinant factors for improving firm , s performance; toward a conceptual model. Procedia Soc Behav Sci [Internet]. 2015;207:786-96. Available from: http://dx.doi.org/10.1016/j.sbspro.2015.10.168

\section{AUTHORS PROFILE}

First Author Anton Wardaya is Doctoral Student at Doctor of Research Management program in Entrepreneurship and Innovation stream, at Bina Nusantara University, Indonesia. He is a lecturer in Business Creation, Bina Nusantara University

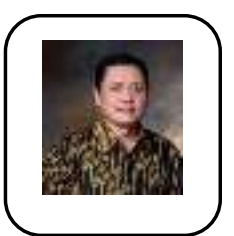

Second Author. Professor Sasmoko is the leader in the Research interest Group in Educational Technology, Bina Nusantara University. He graduated from Education Management from Jakarta State University.

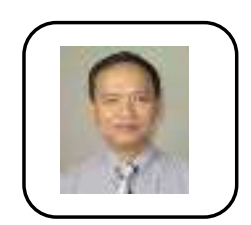

Third Author Idris Gautama So is former vicerector Global Employability and Entrepreneurship, former dean, school of business management and also lecturer in Bina Nusantara University. He is graduated Doctoral from Universiti Sains Malaysia

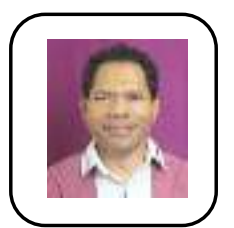

Fouth Author Agustinus Bandur is graduated Doctor of Philosophy (Ph.D) in Leadership and Management Education from The University of Newcastle, Australia. Senior Lecturer \& Strategic Research and Partnership Team Leader 